\title{
The effects of coconut oil supplementation on the body composition and lipid profile of rats submitted to physical exercise
}

\author{
NATHÁLIA M. RESENDE ${ }^{1,2}$, HENRIQUE R. FÉLIX ${ }^{1}$, MURILLO R. SORÉ ${ }^{1}$, ANÍBAL \\ M.M. NETO ${ }^{1}$, KLEBER E. CAMPOS ${ }^{2}$ and GUSTAVO T. VOLPATO ${ }^{2}$
}

\author{
${ }^{1}$ Instituto de Ciências Biológicas e da Saúde, Universidade Federal de Mato Grosso/ UFMT, Campus \\ Universitário do Araguaia, Av. Universitária, 3500, 78698-000 Pontal do Araguaia, MT, Brasil \\ ${ }^{2}$ Instituto de Ciências Biológicas e da Saúde, Laboratório de Fisiologia de Sistemas e Toxicologia \\ Reprodutiva, Universidade Federal de Mato Grosso/ UFMT, Campus Universitário do \\ Araguaia, Av. Valdon Varjão, 6390, 78600-000 Barra do Garças, MT, Brasil
}

Manuscript received on May 15, 2015; accepted for publication on July 21, 2015

\begin{abstract}
This study aims to verify the effects of coconut oil supplementation (COS) in the body composition and lipid profile of rats submitted to physical exercise. The animals ( $\mathrm{n}=6$ per group) were randomly assigned to: G1=Sedentary and Non-supplemented (Control Group), G2=Sedentary and Supplemented, G3=Exercised and Non-supplemented and G4=Exercised and Supplemented. The COS protocol used was $3 \mathrm{~mL} / \mathrm{Kg}$ of body mass by gavage for 28 days. The physical exercise was the vertical jumping training for 28 days. It was determined the body mass parameters, Lee Index, blood glucose and lipid profile. The COS did not interfere with body mass, but the lean body mass was lower in G3 compared to G2. The final Lee Index classified G1 and G2 as obese $(>30 \mathrm{~g} / \mathrm{cm})$. The lipid profile showed total cholesterol was decreased in G3, LDL-c concentration was decreased in G2, triglycerides, VLDL-c and HDL-c concentrations were increased in $\mathrm{G} 2$ and $\mathrm{G} 4$ in relation to G1 and G3. The COS decreased LDL-c/HDL-c ratio. In conclusion, the COS associated or not to physical exercise worsen others lipid parameters, like triglycerides and VLDL-c level, showing the care with the use of lipid supplements.
\end{abstract}

Key words: Cocos nucifera, LDL-c/HDL-c ratio, lipid profile, nutrition, rats, vertical jumping training.

\section{INTRODUCTION}

The coconut oil is a food supplement derived from the Cocos nucifera of Cocoideae subfamily and Arecaceae family. This fruit is a fibrous drupe that consists of a thin hard skin called exocarp, a thicker layer of fibrous mesocarp, the hard endocarp, the white endosperm called kernel, and a large cavity filled with liquid (Chan and Elevitch 2006). The

Correspondence to: Nathália Maria Resende

E-mail: nathy_resende@yahoo.com.br oil is obtained of coconut kernel and it is a natural functional food rich in medium-chain triglycerides (MCTs), mainly the saturated fatty acids with approximately $50 \%$ of the lauric acid (Liau et al. 2011). The lauric acid has potential virucidal and bactericidal actions (Lieberman et al. 2006). It is absorbed directly into the portal circulation and transported to the liver for rapid oxidation. This mechanism could increase energy expenditure, decrease their deposition into adipose tissue and result in faster satiety (St-Onge and Jones 2002). 
It may provide an ideal food source to reduction of the body fat, especially in the abdominal region (Assunção et al. 2009).

The accumulated fat is associated with increased cardiovascular risk, insulin resistance and dyslipidemia (Lippi et al. 2006, Misra et al. 2010). The popular use of coconut oil supplementation (COS) can reduce the accumulated fat. To carry changes in body composition and assisting the obesity status, some life style changes are necessary, mainly about food choices and regular physical exercises programs (Lee et al. 2008, WHO 2008).

Among the physical exercise programs, the vertical jumping training seems to be the most complete plyometric exercise, once during its execution it is used the major muscular groups, mainly the lower limbs muscles (Markovic 2007, Leontijevic et al. 2012, Lamas et al. 2012). Moreover, there are no specific data about lipid prolife determinations and vertical jumping training.

Although the physical exercise or COS using is increased for obesity treatment, there are no studies in literature about the association of both strategies. In this way, we hypothesized exercise changes body composition and lipids in the organism, and the COS can improve these alterations. Therefore, this study aims to verify the effects of COS in the body composition and lipid profile of rats submitted to physical exercise.

\section{MATERIALS AND METHODS}

\section{ANIMALS}

Twenty-four adult female Wistar rats $(140 \pm 3 \mathrm{~g}, 8$ weeks old) were kept on a normal light/dark cycle (12 hours) in a climate-controlled environment $\left(25^{\circ} \mathrm{C}\right)$ throughout the study. The choice to use female rats in this study was based on the hypothesis of Sandoval et al. (2012), that showed that females may have evolved increased sensitivity to fat availability in order to spare glucose for longer periods of food scarcity or stress, such as during exercise.
The animals were maintained in collective cages and also were fed with laboratory chow $\left(\right.$ Purina $^{\circledR}$ ) and tap water ad libitum and cared for in accordance with the principles of the Guide for Care and Use of Experimental Animals. The local Committee of Ethics in Animal Experimentation approved all experimental procedures of this study (\#117/2007).

The animals were randomly assigned to the following groups ( $\mathrm{n}=6$ animals/group): $\mathrm{G} 1=$ Sedentary and Non-supplemented (Control Group), G2 $=$ Sedentary and Supplemented Group, G3 = Physical Exercise and Non-supplemented Group and G4 $=$ Physical Exercise and Supplemented Group.

\section{SUPPLEMENTATION}

The COS protocol used was $3 \mathrm{~mL} / \mathrm{Kg}$ of body mass (bm) which resulted in an average dose of $0.5 \mathrm{~mL}$ per animal by gavage for 28 days since the administration was only in the morning period for G2 and G4 rats (Nevin and Rajamohan 2006). The G1 and G3 rats were treated with $1 \mathrm{~mL}$ of water at same period and administration method.

\section{PHYSICAL EXERCISE TRAINING}

For physical exercise, it was utilized the vertical jumping training which consisted by keeping the animals in the position of the weight lifting machine with electrical stimulation (Tamaki et al. 1992). The vertical jumping training was used for same 28 days of coconut oil supplementation, immediately after the supplementation protocol. The adaptation period of the rats in the weight lifting machine was for 7 days, suggesting the same physical exercise intensity that was about 15 repetitions with electrical stimulation of $1 \mathrm{~Hz}$ per $1 \mathrm{~ms}$ on active cycle of 2:4 and intensity of $4 \mathrm{~mA}-8 \mathrm{~mA}$. The loads was progressive and consisted of without load in the first week (familiarization phase), $100 \% \mathrm{bm}$ in the second week, $200 \% \mathrm{bm}$ in the third week and $300 \% \mathrm{bm}$ in the fourth week. This protocol training is considered of high intensity. 
The $\mathrm{G} 1$ and $\mathrm{G} 2$ rats remained in rest without any intervention during all experimental period.

\section{BODY COMPOSITION}

The anthropometric data (bm and naso-anal length) were measured weekly using an analytical balance and measuring tape to determine the Lee Index. This parameter was calculated as follows: body $\operatorname{mass}^{1 / 3}(\mathrm{~g}) /$ nasal-anal length $(\mathrm{cm}) \times 10$, for which a value equal to or lower than $30 \mathrm{~g} / \mathrm{cm}$ was classified as normal, and value higher than $30 \mathrm{~g} / \mathrm{cm}$ was classified as obese (Bernardis and Patterson 1968, Campos et al. 2008, Lobato et al. 2012).

At the end of the experimental period, the animals were kept in overnight fasting, and the morning after they were submitted to last vertical jumping training. To verify the acute effect of the exercise after 28 days of intervention, the rats were killed by decapitation immediately after the exercise session, followed by the collection of blood samples for biochemical analyses and subcutaneous adipose tissue dissection (Mann et al. 2014). The lean bm was determined by weighting the animal after subcutaneous adipose tissue dissection.

\section{BIOCHEMICAL ANALYSES}

Serum concentrations of glucose, total cholesterol (CHO), triglycerides (TG), high-density lipoprotein (HDL-c), and low-density lipoprotein (LDL-c) were determined by using the enzymatic method (Young 2000), by Labtest ${ }^{\circledR}$ (Minas Gerais state, Brazil) assay kits. Moreover, the serum very-lowdensity lipoprotein (VLDL-c) data was through the triglyceride concentrations (Friedewald et al. 1972). The values were expressed in milligrams (mg) per deciliter (dL) in all serum biomarkers.

\section{STATISTICAL ANALYSES}

The Grubb's test detected the outliers in the samples. To verify the data distribution, the D'Agostino-
Pearson and Shapiro-Wilk normality test was used. For comparison between experimental groups was used the ordinary one-way ANOVA and HolmSidak's multiple comparisons test. The statistical differences were considered to $p$ value $\leq 0.05$.

\section{RESULTS}

The body composition of the rats is showed in Figures 1 to 3 . The COS did not interfere with body mass from sedentary or physical exercise groups compared to their respective Non-supplemented groups (Figure 1). The lean body mass was statistically lower in physical exercised (G3) compared to sedentary with COS group (G2) (Figure 2). The initial and final Lee Index did not statistically differ in any groups related to control group (Figure 3 ), but in the end of the experimental period the animals of sedentary groups (G1 and G2) were classified as obese ( $>30 \mathrm{~g} / \mathrm{cm})$.

Table I shows the biochemical parameters of all rats. There were no significant differences among the four experimental groups in blood glucose data. Total cholesterol was decreased in G3 group when compared to other groups. Triglycerides, VLDL-c and HDL-c concentrations

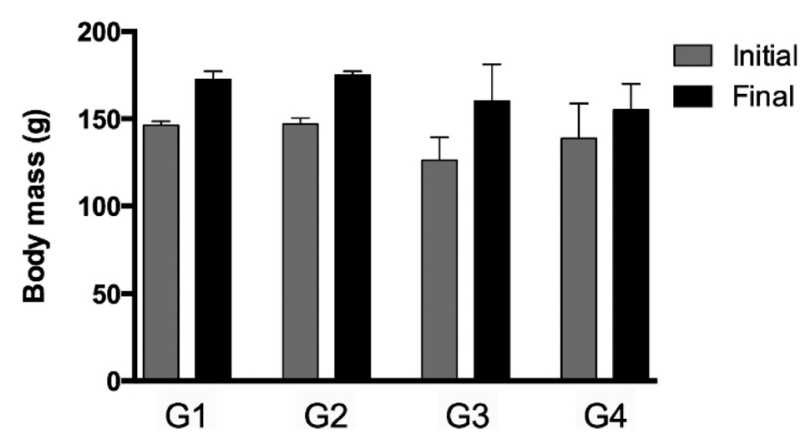

Figure 1 - Initial and final body mass $(\mathrm{g})$ of non-exercised and exercised rats supplemented or not with coconut oil. Data shown as mean \pm standard error. G1 = Sedentary and Non-supplemented (Control Group), G2 = Sedentary and Supplemented Group, G3 = Physical Exercise and Nonsupplemented Group, and G4 = Physical Exercise and Supplemented Group. Non-significance (ANOVA followed by Holm-Sidak test). 


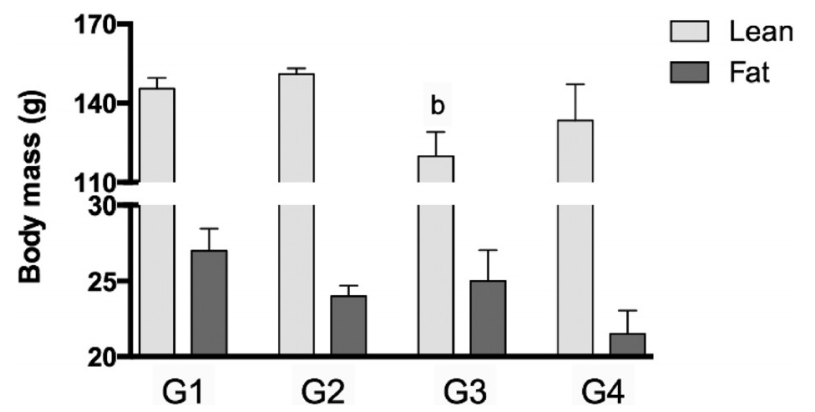

Figure 2 - Lean and fat body mass ( $\mathrm{g}$ ) of non-exercised and exercised rats supplemented or not with coconut oil. Data shown as mean \pm standard error. G1 $=$ Sedentary and Non-supplemented (Control Group), G2 = Sedentary and Supplemented Group, G3 = Physical Exercise and Nonsupplemented Group, and G4 = Physical Exercise and Supplemented Group. ${ }^{\mathrm{b}} \mathrm{p}<0.05=$ Significance difference of the G2 (ANOVA followed by Holm-Sidak test).

were increased in supplemented groups (G2 and G4) in related to Non-supplemented groups (G1 and G3). The LDL-c concentration was decreased in sedentary supplemented group (G2) compared to control group (G1). The exercised groups (G3 and

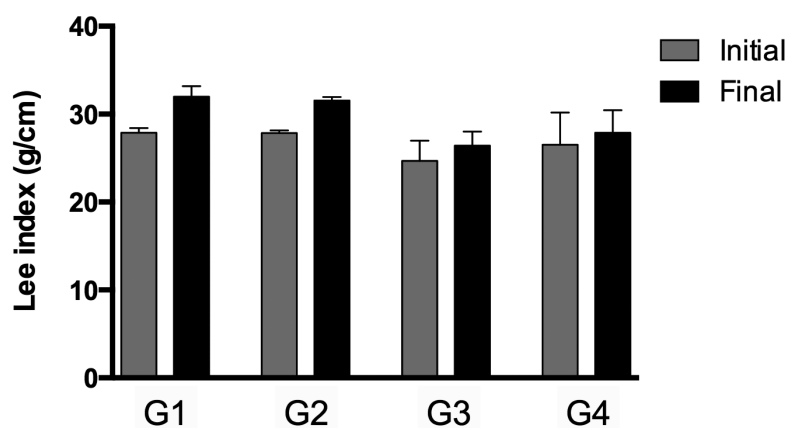

Figure 3 - Initial and final Lee Index $(\mathrm{g} / \mathrm{cm})$ of non-exercised and exercised rats supplemented or not with coconut oil. Data shown as mean \pm standard error. G1 $=$ Sedentary and Non-supplemented (Control Group), G2 = Sedentary and Supplemented Group, G3 = Physical Exercise and Nonsupplemented Group, and G4 = Physical Exercise and Supplemented Group. Non-significance (ANOVA followed by Holm-Sidak test).

G4) present lower LDL-c concentration compared to sedentary groups (G1 and G2). The exercise and COS decreased LDL-c/HDL-c ratio compared to control group, and the G4 group presented decrease in this parameter compared to G2 group.

TABLE I

Biochemical analyses of non-exercised and exercised rats supplemented or not with coconut oil.

\begin{tabular}{lcccc}
\hline & \multicolumn{4}{c}{ Groups } \\
\cline { 2 - 5 } & $G 1$ & $G 2$ & $G 3$ & $G 4$ \\
\hline Glucose (mg/dL) & $123.3 \pm 5.0$ & $152.4 \pm 13.1$ & $135.5 \pm 5.1$ & $142.0 \pm 9.9$ \\
Total Cholesterol (mg/dL) & $118.5 \pm 1.0$ & $140.8 \pm 5.8$ & $80.5 \pm 10.3^{\mathrm{a}, \mathrm{b}, \mathrm{d}}$ & $118.0 \pm 7.3$ \\
Triglycerides (mg/dL) & $113.2 \pm 1.3$ & $195.2 \pm 18.8^{\mathrm{a}}$ & $102.5 \pm 19.8^{\mathrm{b}, \mathrm{d}}$ & $187.7 \pm 20.6^{\mathrm{a}}$ \\
HDL-c (mg/dL) & $32.7 \pm 2.5$ & $59.4 \pm 4.9^{\mathrm{a}}$ & $44.8 \pm 2.6^{\mathrm{d}}$ & $65.6 \pm 5.5^{\mathrm{a}}$ \\
LDL-c (mg/dL) & $63.1 \pm 2.1$ & $42.4 \pm 5.2^{\mathrm{a}}$ & $15.2 \pm 5.1^{\mathrm{a}, \mathrm{b}}$ & $14.8 \pm 3.0^{\mathrm{a}, \mathrm{b}}$ \\
VLDL-c (mg/dL) & $22.6 \pm 0.3$ & $39.0 \pm 3.8^{\mathrm{a}}$ & $20.5 \pm 4.0^{\mathrm{b}, \mathrm{d}}$ & $37.5 \pm 4.1^{\mathrm{a}}$ \\
LDL-c/HDL-c & $1.7 \pm 0.1$ & $0.6 \pm 0.1^{\mathrm{a}}$ & $0.3 \pm 0.1^{\mathrm{a}}$ & $0.2 \pm 0.1^{\mathrm{a}, \mathrm{b}}$ \\
\hline
\end{tabular}

Data shown as mean \pm standard error. G1 = Sedentary and Non-supplemented Group (Control Group), G2 = Sedentary and Supplemented Group, G3 = Physical Exercise and Non-supplemented Group, and G4 = Physical Exercise and Supplemented Group. ANOVA followed by Holm-Sidak test. ${ }^{\mathrm{a}} \mathrm{p}<0.05$ compared to G1 group. ${ }^{\mathrm{b}} \mathrm{p}<0.05$ compared to G2 group. ${ }^{\mathrm{p}} \mathrm{p}<0.05$ compared to G3 group. ${ }^{\mathrm{d}} \mathrm{p}<0.05$ compared to G4 group.

\section{DISCUSSION}

Several studies showed the physical exercise practice associated to properly diet as a strategy to prevent the obesity status and its current metabolic diseases (Durstine et al. 2002, Ilić et al. 2012). It used weight training with high intensity, specifically the vertical jumping training, as a resistance physical exercise model to increase the energy demand (Franco et al. 2011). According to Tamaki et al. (1992), the weight training reduces fat body mass and/or increases muscular and bone mass. It also may increase strength, resistance and 
muscular power, and improves the cardiorespiratory system. Associated with physical exercise, the supplementation is used as promoter changes in body composition. Rolland et al. (2002) showed soybean oil intake in sedentary rats increased the weight of lean tissues besides muscles. The G3 group had the lean mass decreased when compared to the data of the sedentary and supplementary group $(\mathrm{G} 2)$. In the same way, others studies observed that rats with oil supplementation had higher subcutaneous fat and body mass (Bell et al. 2011, Yamazaki et al. 2011). Also, Ippagunta et al. (2011) demonstrated that animals fed with COS have a lower body mass gain when compared to animals fed with a rich diet on long-chain triglycerides like soy oil.

The Lee Index is a biomarker very used to identify the obesity state that is equivalent to body mass index (BMI) in humans (WHO 2008, Misra et al. 2010). The Lee Index was effective to confirm the anthropometric profiles and adiposity in the rats and can be used as an indicator of body fat excess (Bernardis and Patterson 1968). In the end of the experimental period, the sedentary groups (G1 and G2) had the adiposity increased. However, the COS was not what caused the increase of fat body mass, but rather the sedentarism. Studies confirmed that regular exercise practice alter the body composition and mobilize the fatty acids absorption, increasing the lean mass and reducing the fat body mass (Caponi et al. 2013, Nery et al. 2011).

Is it known the physical exercise decreases glucose levels (Lalanza et al. 2012, McNeilly et al. 2012). Although the glycemia did not differ in both groups, the physical exercise and/or COS may influence someway to decrease this biomarker. This tendency to decrease of glucose levels points that the energetic sources used to generate energy system during physical exercise, associated or not with COS. On this system, the aerobic energy production on the muscular cells is ensured by the mitochondrial oxidation of the carbohydrates and lipids, with lower contribution of the amino acids (Brooks et al. 2000).
The effects of physical exercise on the lipid metabolism have been widely studied. Physical exercise practitioners have probably better lipidic profile, presenting as higher HDL-c and lower LDL-c and VLDL-c compared to sedentary ones (Campaigne et al. 1993, Schoenfeld et al. 2014). This study showed that the physical exercise decreased triglycerides, total cholesterol, LDL-c and VLDL-c levels, and improve LDL-c/HDL-c ratio, but did not alter HDL-c level. These data partially corroborate with other studies, which showed that the exercise training enhances the use of fatty acids resulting in elevated lipoprotein lipase activity, that is associated with decreases in plasma total cholesterol and increases in HDL-c (Suzuki et al. 2011, Frisch and Sumida 2009, Mela and KrisEtherton 1984). There are studies that show that one of the biggest benefits from regular physical exercise is improvement in the lipid profile, but this is only observed in the long period (Thomas and La Fontaine 1988). The HDL-c level in our study did not change because the period training possibly was not sufficient to increase the HDL-c concentration.

The population use several alternative methods to lose fat body mass, like COS using (Assunção et al. 2009). It has been reported in studies that COS presents many health benefits, like hypocholesterolemic, hypolipemic, antiplaque, antioxidant and antidiabetic properties. The major fatty acids content from COS is medium-chain lauric acid and it converts into monolaurin that are easily digested, absorbed and utilized by the body and contribute less fat deposition (Hegde 2006, Benson et al. 2008). In our study was observed the COS increased triglycerides and VLDL-c. However, the COS decreased LDL-c and increased HDL-c, and also improved the LDL-c/HDL-c ratio. Coconut oil has the medium-chain triglycerides that are directly absorbed to the blood flow right after supplementation. We suggest in this study, euthanasia procedure was done after COS and the 
training session, which could explain the increased plasmatic triglyceride and VLDL-c release to produce energy in both supplemented groups. However, only the supplemented and exercised group (G4) had energetic requirement during the training protocol.

Physical exercise associated with diet have been recommended as first-line therapy for dyslipidemia, and good evidence supports the use of these interventions at reducing LDL-c, blood pressure and body mass (Murff 2002). In the association of COS and exercise, the data were the same of sedentary rats that received only COS. Therefore, the reduction of LDL-c and LDL-c/ HDL-c ratio was more evident on the group that practiced physical exercises associated with COS. The reduction of the LDL-c and the increase of HDL-c associated with regular exercise can be explained into intracellular enzymes by betaoxidation (Berg et al. 1994, Nevin and Rajamohan 2006). After exercise training occurs an increase on the lecithin-cholesterol acyltransferase enzyme, which reduces the catabolism of the HDL-c, and leads a possible increase its concentrations (Bleicher and Lacko 1992, Seip et al. 1993). According to Bomtempo (2008) and Barbalho et al. (2011), the COS leads an increase of HDL-c and decreases LDL-c, helping on the prevention of atherosclerosis and coronary diseases. Besides, it reduces the risk of cancer, regularizes the intestinal rhythm, improves glycemic control, weight loss by the lipid metabolism, prevents osteoporosis, increases the energy level by its antioxidant action and reduces the aging process. The lipoproteins data showed an increase of HDL-c and decrease of LDL-c in COS groups.

In conclusion, the physical exercise enhanced the body composition, avoiding the increase of adiposity. However, the COS improved LDL-c and HDL-c levels, and consequently LDL-c/HDL-c ratio, and the association with physical exercise exacerbated this findings. Also the COS, associated or not to physical exercise, worsened others lipid parameters, such as plasmatic triglycerides and VLDL-c level, showing the care with the use of lipid supplements.

\section{RESUMO}

Este estudo tem como objetivo verificar os efeitos da suplementação de óleo de coco (SOC) na composição corporal e no perfil lipídico de ratos submetidos ao exercício físico. Os animais ( $\mathrm{n}=6$ por grupo) foram divididos aleatoriamente em: $\mathrm{G} 1=$ sedentários e nãosuplementados (Grupo Controle), G2=sedentários e suplementados, $\mathrm{G} 3=$ exercitados e não-suplementados e G4=exercitados e suplementados. O protocolo da SOC foi $3 \mathrm{~mL} / \mathrm{Kg}$ de massa corporal por gavagem durante 28 dias. O exercício físico foi o treinamento de salto vertical durante 28 dias. Foram avaliados o perfil da massa corporal, Índice de Lee, glicemia e perfil lipídico. A SOC não modificou a massa corporal, mas a massa corporal magra foi menor no G3 em relação ao G2. O Índice de Lee final classificou G1 e G2 como obesos $(>30 \mathrm{~g} / \mathrm{cm})$. O perfil lipídico mostrou que o colesterol total estava menor no G3, a concentração de LDL-c estava menor no G2, as concentrações de triglicerídeos, VLDL-c e HDL-c estavam maiores nos G2 e G4 em relação aos G1 e G3. A suplementação promoveu diminuição da razão LDL-c/HDL-c. Conclui-se que a SOC associada ou não ao exercício físico piora alguns parâmetros lipídicos, como os níveis de triglicerídeos e VLDL-c, sugerindo cuidado com o uso de suplementos lipídicos.

Palavras-chave: Cocos nucifera, razão LDL-c/HDL-c, perfil lipídico, nutrição, ratos, treinamento de salto vertical

\section{REFERENCES}

ASSUNÇÃO ML, FERREIRA HS, DOS SANTOS AF, CABRAL CR JR AND FLORÊNCIO TM. 2009. Effects of dietary coconut oil on the biochemical and anthropometric profiles of women presenting abdominal obesity. Lipids 44(7): 593-601.

BARBALHO SM ET AL. 2011. Effect of continuous and interval physical exercise on weight and biochemical profile of pregnant Wistar rats and consequences on fetal body weight. Rev Bras Med Esp 17(6): 413-415.

Bell ZW, CANALE RE AND BloOMER RJ. 2011. A dual investigation of the effect of dietary supplementation with licorice flavonoid oil on anthropometric and biochemical 
markers of health and adiposity. Lipids Health Dis 2(10):10-29.

BENSON MK, KSHAMA D AND FATTEPUR SR. 2008. Studies on SFA/TFA (saturated/trans fatty acid) rich dietary fats on lipid profile and antioxidant enzymes in normal and stressed rats. Phoog Mag 4(16): 320-328.

Berg A, Frey I, Baumstark MW, Halle M AND Keul J. 1994. Physical activity and lipoprotein lipid disorders. Sports Med 17(1): 6-21.

BERNARDIS LL AND PATTERSON BD. 1968. Correlation between "Lee index" and carcass fat content in weanling and adult female rats with hypothalamic lesions. J Endocrinol 40(4): 527-528.

BLEICHER J AND LACKO A. 1992. Physiologic role and clinical significance of reserve cholesterol transport. J Am Ostheophat Assoc 92(5): 625-632.

Bomtempo M. 2008. O poder Medicinal do Coco e do Óleo de Coco Extra Virgem. São Paulo: Editora Alaude.

BROOKS GA, FAHEY TD, WHITE TP AND BALDWIN KM. 2000. Exercise Physiology: Human Bioenergetics and its applications. $3^{\text {rd }}$ ed., Macmillan Publishing Company. New York.

CAMPAIgNE BN, FONTAINE RN, PARK MS AND RYMASZEWSKI ZJ. 1993. Reverse cholesterol transport with acute exercise. Med Sci Sports Exerc 25(12): 13461351.

CAmpos Ke, Volpato GT, CALderon IM, Rudge MV AND DAMASCENO DC. 2008. Effect of obesity on rat reproduction and on the development of their adult offspring. Braz J Med Biol Res 41(2): 122-125.

CHAN E AND ELEVITCH CR. 2006. Cocos nucifera (coconut). In: Elevitch CR (Ed), Species Profiles for Pacific Island Agroforestry. Permanent Agriculture Resources (PAR), Hōlualoa.

CAPONI PW ET AL. 2013. Aerobic exercise training induces metabolic benefits in rats with metabolic syndrome independent of dietary changes. Clinics (São Paulo) 68(7): 1010-1017.

DURSTINE JL, GRANDJEAN PW, COX CA AND THOMPSON PD. 2002. Lipids, lipoproteins, and exercise. J Cardiopulm Rehabil 22(6): 385-398.

FRANCO FS, COSTA NM, FERREIRA SA, CARNEIRO-JUNIOR MA AND NATALI AJ. 2011. The effects of a high dosage of creatine and caffeine supplementation on the lean body mass composition of rats submitted to vertical jumping training. J Int Soc Sports Nutr 1(8): 3.

FRIEDEWALD WT, LEVY RI AND FREDRICKSON DS. 1972. Estimation of the concentration of low-density lipoprotein cholesterol in plasma, without use of preparative ultracentrifuge. Clin Chem 18(6): 499-502.

FRISCH F AND SUMIDA KD. 1999. Strength training does not alter the effects of testosterone propionate injections on high-density lipoprotein cholesterol concentrations. Metabolism 48(12): 1493-1497.
HEGDE BM. 2006. Coconut oil: Ideal fat next only to mother's milk (scanning coconut's horoscope). JIACM 7: 16-19.

Ilić D, Ilić V, MRDAKOVIĆ V AND FiLipović N. 2012. Walking at speeds close to the preferred transition speed as an approach to obesity treatment. Srp Arh Celok Lek 140(1-2): 58-64.

IPPAGUNTA S, HADENFELDT TJ, MINER JL AND HARGRAVEBARNES KM. 2011. Dietary conjugated linoleic acid induces lipolysis in adipose tissue of coconut oil-fed mice but not soy oil-fed mice. Lipids 46(9): 821-830.

LALANZA JF, SANCHEZ-ROIGE S, GAGLIANO H, FUENTES S, BAYOD S, CAMINS A, PALLÀS M, ARMARIO A AND ESCORIHUELA RM. 2012. Physiological and behavioural consequences of long-term moderate treadmill exercise. Psychoneuroendocrinology 37(11): 1745-1754.

LAMAS L, UGRINOWITSCH C, RODACKI A, PEREIRA G, MATtOs E, KOHN A AND TRICOLI V. 2012. Effects of strength and power training on neuromuscular adaptations and jumping movement pattern and performance. J Strength Cond Res 26(12): 3335-3344.

LEE K, SONG YM AND SUNG J. 2008. Which obesity indicators are better predictors of metabolic risk?: healthy twin study. Obesity (Silver Spring) 16(4): 834-840.

LIEBERMAN S, ENIG MG AND PREUSS HG. 2006. A review of monolaurin and lauric acid: Natural virucidal and bactericidal agents. Altern Complem Ther 12(6): 310-314.

Leontijevic B, PAZIN N, BoziC PR, Kukolj M, UGARKOVIC D AND JARIC S. 2012. Effects of loading on maximum vertical jumps: Selective effects of weight and inertia. J Electromyogr Kinesiol 22(2): 286-293.

LIAU KM, LEE YY, CHEN CK AND RASOOL AH. 2011. An open-label pilot study to assess the efficacy and safety of virgin coconut oil in reducing visceral adiposity. ISRN Pharmacol 3(15): 1-7.

Lippi G, Schena F, Salvagno GL, Montagnana M, BALLESTRIERI F AND GUIDI GC. 2006. Comparison of the lipid profile and lipoprotein(a) between sedentary and highly trained subjects. Clin Chem Lab Med 44(3): 322326.

LOBATO NS ET AL. 2012. Improvement of metabolic parameters and vascular function by metformin in obese non-diabetic rats. Life Sci 90(5-6): 228-235.

MANN A, THOMPSON A, RoBBINS N AND BLOMKALNS AL. 2014. Localization, identification, and excision of murine adipose depots. J Vis Exp 12(4): 94.

MARKOVIC G. 2007. Does plyometric training improve vertical jump height? A meta-analytical review. Br J Sports Med 41(6): 349-355.

MCNeILly AM, MCClean C, Murphy M, MCENENy J, TRINICK T, Burke G, DULY E, MCLAUGhlin J AND DAVISON G. 2012. Exercise training and impaired glucose tolerance in obese humans. J Sports Sci 30(8): 725-732.

MELA DJ AND KRIS-ETHERTON PM. 1984. The effects of exercise and a moderate hypercholesterolemic diet on 
plasma and hepatic lipoproteins in the rat. Metabolism 33(10): 916-921.

MisRA A, Singhal N AND KhuRANA L. 2010. Obesity, the metabolic syndrome, and type 2 diabetes in developing countries: role of dietary fats and oils. J Am Coll Nutr 29(3 Suppl): 289S-301S.

MURFF HJ. 2002. Diet and exercise for dyslipidemia: the challenge of putting guidelines into practice. J Clin Outcome Man 9(10): 550-551.

NERY CS ET AL. 2011. Murinometric evaluations and feed efficiency in rats from reduced litter during lactation and submitted or not to swimming exercise. Rev Bras Med Esporte 17(1): 49-55.

NEVIN KG AND RAJAMOHAN T. 2006. Virgin coconut oil supplemented diet increases the antioxidant status in rats. Food Chem 99(2): 260-266.

ROLLAND V, ROSEAU S, FROMENTIN G, NICOLAIDIS S, TOMÉ D AND EVEN PC. 2002. Body weight, body composition, and energy metabolism in lean and obese Zucker rats fed soybean oil or butter. Am J Clin Nutr 75(1): 21-30.

SANDOVAL DA, RYAN KK, DE KLOET AD, WOODS SC AND SEELEY RJ. 2012. Female rats are relatively more sensitive to reduced lipid versus reduced carbohydrate availability. Nutr Diabetes 2(2): e27.

SCHOENFELd BJ, ARAGON AA, WiLbORN CD, KRIEGER JW AND SONMEZ GT. 2014. Body composition changes associated with fasted versus non-fasted aerobic exercise. J Int Soc Sports Nutr 11(1): 54-60.
SEIP RL ET AL. 1993. Exercise training decreases plasma cholesteryl ester transfer protein. Arterioscler Thromb 13(9): 1359-1367.

ST-ONGE MP AND JONES PJ. 2002. Physiological effects of medium-chain triglycerides: potential agents in the prevention of obesity. J Nutr 132(3): 329-332.

SUZUKI M, SHINDO D, KIMURA M AND WAKI H. 2011. Effects of exercise, diet, and their combination on metabolicsyndrome-related parameters in OLETF rats. Int J Sport Nutr Exerc Metab 21(3): 222-232.

TAMAKI T, UCHIYAMA S AND NAKANO S. 1992. A weightlifting exercise model for inducing hypertrophy in the hindlimb muscles of rats. Med Sci Sports Exerc 24(8): 881-886.

THOMAS TR AND LA FonTAINE T. 1998. Exercise and lipoproteins. In: Willian and Wikins (Eds), ACSM resource manual for guidelines for exercise testing and prescription, p. 294-301.

WHO - WORD HEAlTh ORganization. 2008. Preventing noncommunicable diseases in the workplace through diet and physical activity: WHO/World Economic Forum report of a joint event.

YAMAZAKI RK ET AL. 2011. Low fish oil intake improves insulin sensitivity, lipid profile and muscle metabolism on insulin resistant MSG-obese rats. Lipids Health Dis 4(10): 66-72.

YOUNG DS. 2000. Effects of drugs on clinical laboratory tests. $5^{\text {th }}$ ed., London, UK: AACC Press. 